Brazilian Journal of Political Economy, vol. 41, nº 4, pp. 782-796, October-December/2021

\title{
An assessment of the debates over income distribution and growth in the Neo-Kaleckian literature
}

\author{
Uma avaliação dos debates sobre distribuição de renda \\ e crescimento na literatura neokaleckiana
}

SULAFA NOFAL ${ }^{*}$

RESUMO: A literatura kaleckiana é considerada um tema importante na escola pós-keynesiana de pensamento econômico. No rescaldo da crise financeira, os esforços para a formação de um novo consenso sobre as questões econômicas essenciais, em particular o crescimento econômico, tornaram-se uma necessidade. Assim, os modelos kaleckianos voltaram a estar em evidência, uma vez que esses modelos enfrentam o impacto das mudanças na distribuição da renda e questionam se uma redistribuição da renda fora dos salários para o lucro é capaz de impulsionar o crescimento. Nesse sentido, este artigo retorna aos insights kaleckianos e oferece uma discussão teórica dos efeitos distributivos sobre a demanda agregada e o crescimento econômico. Além disso, através das lentes da tradição neokaleckiana, pode-se rastrear a evolução do debate sobre os regimes movidos pelos salários e pelos lucros nas últimas décadas.

PALAVRAS-CHAVE: Crescimento econômico; distribuição de renda; modelos kaleckianos; wage-led; profit-led.

ABSTRACT: Kaleckian literature is considered an important theme in the post-Keynesian school of economic thought. In the aftermath of the financial crisis, the endeavors of forming a new consensus regarding essential economic issues, in particular achieving economic growth became a need. Thus, the Kaleckian models returned to be in the spot since these models tackle the impact of changes in the distribution of income and address the question whether a redistribution of income away from wages and towards profits is capable of boosting growth. In this sense, this paper return to Kaleckian insights and offers a theoretical discussion of the distributional effects on aggregate demand and economic growth. Moreover, through the lens of neo-Kaleckian tradition, the evolution of the debate on wage-led and profit-led regimes in recent decades can be traced.

KEYWORDS: Economic growth; income distribution; Kaleckian models; wage-led; profit-led. JEL Classification: E21; E12; E11.

\footnotetext{
* PhD student in Economics at Universidade de Brasília - UnB, Brasília/DF, Brasil. E-mail: sulafa.nofal@ yahoo.com. Orcid: https://orcid.org/0000-0002-4429-240X. Submitted: 30/March/2020. Approved: 4/ November/2020.
} 


\section{INTRODUCTION}

Among the most challenging questions in economics are those related to economic growth and income distribution. These questions were posed by the classical economists and have ever been the subject of debate by economists. It, therefore, remains true that "to determine the laws that regulate the distribution of income" as Ricardo declared in his Principles of Political Economy and Taxation (1817: 5) "is the principal problem in political economy". Yet, although these issues have been a major concern for economic theories, there is no clear conventional vision, or even alternative one, that provides much help in understanding many aspects related to the issues of income distribution and economic growth, and the relationship among them. Furthermore, some of the aspects that had some common consensus have collapsed or at least have cracked widely in the wake of the recent financial crisis.

Indeed, over the past decades, the global debate over such essential issues has faltered somewhat in a mess. Economic crises have become more frequent and income inequality, by many measures, has deteriorated more than ever. One can argue that this situation is no more than a reflection of contradictions and lack of consensus on the effective strategies for achieving economic growth and the equitable distribution of wealth. As a result, a rich discussion has been centered around ways to achieve more stable and sustainable forms of growth, since it has often been considered the default mechanism for preventing collapse, especially in the wake of the last financial crisis that have raised many questions related to theories and economic policies that have been followed for more than thirty years.

The failure of economic strategies to achieve growth has brought light back to the ideas that have shaped the current ideology. Among them, as Stiglitz (2016) points out, is the belief that economic growth will benefit all sections of society, or what has become commonly referred to in political and economic contexts by saying that "a rising tide lifts all boats". This idea was translated through strategies that seek to promote the concentration of wealth in the hands of the wealthy classes, arguing that this will motivate entrepreneurs to invest more, leading to higher employment rates and thus bringing the benefit for the working class.

Another aspect highlighted by the financial crisis relates to the allegations that have been marketed not only in terms of the efficiency and stability of financial markets but also to those claiming that wage moderation will lead to a more stable economy and a more productive economic system. Such ideas formed the nucleus of the neoliberal policies that put an end to the conflict of the 1970s and 1980s between capital and labor by shifting income distribution strategies towards the capital. Hein (2015: 15) confirmed that "the increase in top management salaries in the period of neo-liberalism and financialization has dampened the fall in the measured wage share since the early 1980s". Since then, reforms and changes in economic policies have pushed down the wage share in the hope that this decline will stimulate investments and lead to higher growth (Lavoie and Stockhammer, 2013). This justification is used by the mainstream to show this fall in wages as a corollary of technical change caused by the globalization. According to Kohler et 
al (2019: 964) "the opening of domestic financial markets for foreign capital contributed to an erosion of the wage share". And these changes in income distribution, as Stockhammer (2015) reported, led to the wage shares in United states to a decline of 5 percentage points and even more in the European countries that fell by about 10 percentage points.

This shift in income distribution towards suppression of wages has important implications that can be seen clearly through the link between wages and productivity and its influence in the economic growth path. This link is an essential component for fair distribution between labour and capital because rising wages in line with the increase in productivity enhance the households' purchasing power and create an incentive for further economic growth (ILO, 2013).

However, over recent decades wage growth has been lagging behind productivity growth. In this regard, Arestis, Sobreira, and Oreiro (2010) noted that following the aftermath of the Second World War, the decline in real wage rate was accompanied by a significant drop in productivity reaching its lowest point, around 15 percent, during the Korean War (1950-1953). Although this gap between the real wage rate and productivity has diminished in some periods, they indicated that the repercussions of the explosion of internet and housing bubbles, as well as the increase in unemployment, have widened this gap to reach an all-time low of around -20 percent in the wake of the collapse of Lehman Brothers in September 2008. This is in line with the Global Wage Report 2012/13: Wages and equitable growth (ILO, 2013), that indicated the widening productivity-wage gaps in countries such as United States, Japan and more clearly the case of Germany, where average wages decreased, despite the positive growth in average labor productivity in the years 1999-2007. This turmoil caused by lower wages has contributed to creating global economic imbalances rather than increasing investment, i.e., contrary to prevailing claims, which leads to questioning the empirical relevance of investment-driven/ profit-led regimes (Kapeller and Schütz, 2015).

What has been discussed so far may justify the growing calls for the necessity of changes in the prevailing economic policy. Among those voices are Oreiro et al. (2012), who, despite their compatibility with Keynes' view that the determinants of long-term growth should be found on the demand side, stressed the importance of not driving towards stimulating growth through whatever policy that increases aggregate demand. Instead, in the case of Brazil, Oreiro et al. (2012: 153) have proposed a new growth model "in which exports drive aggregate demand and thus serve as the engine of long-run growth. Adopting this growth model, however, requires an exchange-rate regime that can keep the real exchange rate undervalued". This call to adopt new policies to promote growth has also been put forward by Lavoie and Stockhammer (2013:13) who believe that "It is time to reconsider the validity of these pro-capital distributional policies, and to examine the possibility of an alternative path, one based on pro-labour distributional policies, accompanied by legislative changes and structural policies that will make a wage-led growth regime more likely, that is, pursue what we call a wage-led growth strategy, which, in our view, will generate a much more stable growth regime for the future". 
Therefore, in light of the foregoing, it seems clear the importance and necessity of forming a more comprehensive and complete understanding of the issues of economic growth and income distribution, as this is an indispensable step for moving towards finding alternative ways out of the current crises. In this regard, the post-Keynesian school of economic thought is capable of addressing such alternatives paths, in particular, the Kaleckian models, since an important theme in this literature addressing the impact of changes in the distribution of income and whether a redistribution of income away from wages and towards profits is capable of boosting growth. Thus, this paper return to Kaleckian insights and offers a theoretical discussion of the distributional effects on aggregate demand and economic growth. Moreover, through the lens of neo-Kaleckian tradition, the evolution of the debate on wage-led and profit-led regimes in recent decades can be traced.

This paper is structured into four sections following this introduction. The second section briefly discusses the most prominent stages of the evolution of economic growth theory, in a manner that serves later the debate on income distribution and growth models in the Kaleckian tradition. The third section discusses the different views on the motives of economic growth. Then after, the fourth section deals with the economic growth and income distribution in Kaleckian framework. The final section summarizes the conclusions obtained from the dissection.

\section{THEORETICAL DISCUSSION}

Economic growth and income distribution were the main concerns of classical economists, Adam Smith and David Ricardo, as well as Karl Marx. They considered that functional income distribution is determined by socio-institutional factors. Moreover, the fundamental conflict in the classical-Marxian theory of growth and distribution shows the existence of a conflict between wages and profit on one hand, and between consumption and growth on the other hand (Oreiro, 2018).

Growth theory had lost its momentum in several stages of its development which, to a large extent, were not proceeding harmoniously. Although much of early literature relied on the contributions of classical economists as a starting point for developing the debate on aspects of economic growth and income distribution, these contributions were subsequently neutralized in the aftermath of the marginalist revolution in the late nineteenth century, at the expense of the focus on exchange, resource allocation, and price determination. Thus, priority is no longer addressed to growth problems.

The concept of the relationship between the distribution of income and economic growth introduced by classical economists was reverted to be a focus of attention in the 1930s through the works of Keynes who rejected Say's Law and replaced it with the principle of effective demand. It is remarkable that although the issues of growth and distribution were not the main focus that prompted Keynes to write his General Theory, it undoubtedly revealed his profound understanding of the effect of transferring income away from wage-earners on aggregate demand, output, 
and employment. Nevertheless, Hein (2014) mentioned that what constitutes the nucleus of the foundations of post-Keynesian theories of distribution is the ideas that Keynes put forward in his previous book A Treatise on Money.

The development of post-Keynesian growth theory was crystalized through the contributions of Domar, Harrod, Kaldor, Jane Robinson as well as the works of Michal Kalecki and Josef Steindl. Harrod, for example, put forward the concept of warranted growth and developed a model to determine an economy's long-run growth path, seeking to formulate a dynamic model based on the Keynesian macroeconomic framework. However, the equilibrium given by the warranted rate of growth is highly unstable. Although growth with full employment may be possible, it is unlikely to happen. And since the equation's variables are exogenous and independent on each other, it makes it difficult to say inevitably that there is an economic mechanism capable of making these variables assuming the necessary values for the occurrence of a growth trajectory with full employment (Oreiro, 2018). As Pasientti (1974: 97) put it, Harrod-Domar equation "can only be satisfied by a fluke", which turned to be considered as the "knife edge" problem. Moreover, besides the question of stability, there is also the existence question, whether achieving the warranted rate coincides with the natural rate of growth. These issues later became the focus of attention of economists, particularly Kaldor and Pasinetti.

Unlike Harrod who considered the natural rate of growth is exogenous, Kaldor endogenized the natural rate of growth through the technical progress function and he showed the possibility of a stable equilibrium growth path at full employment. In the same context, Oreiro (2018: 128) mentioned that "Kaldor's view is that technical progress is both the cause and the result of economic growth, so any phenomenon that induces an acceleration of growth will be increasing the rate of technical progress. The labor productivity growth rate is assumed to be positively related to the capital stock growth rate per worker. Thus, an increase in the investment rate increases the capital stock and through the Keynesian "multiplier" produces economic growth. Indeed, the larger share of capital per worker makes labor more productive, making growth an endogenous process".

Kalecki, like Keynes, also believes that stimulating demand is capable of achieving full employment. In this regard and for the purpose of stimulating aggregate demand, Kalecki mentioned three methods represented either by deficit spending by government or stimulation of private investment through lower interest rates or targeted tax breaks. In addition to the aforementioned methods, he argues in favor of a third one, which is to redistribute income from the rich to the poor, although he realizes that it is the most politically controversial option. In this sense, from the Kaleckian perspective, the growth model relies fundamentally on the demand stimulated by real wage growth (Baccaro and Pontusson, 2016).

Theories of demand-led growth are associated with the Kaleckian and Kaldorian traditions. However, the contributions to demand-led growth theory were challenged during the 1990s by the neoclassical endogenous growth theory that neglected the possibility that aggregate demand and money supply would have long-term effects in determining economic growth (Setterfield, 2002). But this view has been 
subject to heavy criticism, especially since the last financial crisis, as many government agencies, and central banks have lowered their expectations for real growth in the long run, which indicates that potential growth is affected by weakening aggregate demand, in contrast to what the neo-Classics claim (Lavoie and Stockhammer, 2013).

\section{WHAT DRIVES ECONOMIC GROWTH?}

The contributions of both classical economists and Karl Marx founded the principles underlying long-term growth models and income distribution that were marked by emphasizing the close link between capital accumulation and the distribution of income among the principal social classes. The classical-Marxian approach is centered on the frameworks of economic growth driven by the accumulation of capital by the capitalists. The saving and investment of the capitalists is closely linked to the ability of the production process to generate enough of an economic surplus in the form of profits, thereby establishing the inevitable trade-off or inverse relationship between the profit of capital and the wage of labor. They considered, therefore, that with capitalists allocating a greater share of their profits to savings and investment, the economy would grow faster without any change in the distribution of income between wages and profits. That is, they did not take the role of the demand side factor in affecting long-term growth (Blecker and Setterfield, 2019). However, their visions, as Lavoie and Stockhammer (2013) noted, was clashed with the visions of reformism within the workers' movement, especially in the context of the phenomenon of 'underconsumption'. At the time, the hypothesis of underconsumption was not taken seriously, because the factors that were seen as determinants of long-term growth were limited to those associated with the supply side such as the growth rate of the labour force and the growth rate of labour productivity. While those factors are relevant, this view leaves other fundamental aspects out of the analysis because it considers that the path of economic growth is independent of variations in demand. More specifically, it assumes that the effect of changes in aggregate demand on the utilization of resources is limited to the short term, whereas, in the long term, changes in demand have no direct, or even indirect, influence on economic growth. This assumption stems from the idea that savings create investment, which makes it impossible for effective demand to be deficient and thus this approach has focused only on the supply side (Setterfield, 2002).

Keynes provided a better and more complete understanding of how aggregate demand determines the functional distribution of income. Keynesian perspective emphasizes demand-side factors, that the growth of supply adjusts to the growth of demand, not the other way around. The demand-side perspective thus gave new insights into the role of wages as an engine of economic growth. Consequently, the intervention of government in economic processes, whether through direct impact on investment spending or by influencing the conditions of demand, has an impact on the economic growth. 
The principle of effective demand developed by Keynes has shaken the premise that what is saved is automatically invested, and thus opened the door to a new wave of growth models, or what has come to be known as post-Keynesian models. The contribution of these models provided an important clarification about the relationship between income distribution and effective demand.

Most of the classical-Marxian, and neo-Keynesian approaches claim that technological improvement is the only way to achieve a kind of equitable growth. Otherwise, achieving rapid economic growth will take place in a situation of inequality in income distribution. This link between the requirements of rapid economic growth and the redistribution of income towards profits was undoubtedly a matter of concern about the implications of the unequal income distribution (Blecker and Setterfield, 2019).

Since then, the perception of the relationship between functional income distribution and economic growth has been the subject of debate by several economic paradigms: the neoclassical., the Keynesian and the post-Keynesian. Meanwhile, following these different paradigms, it becomes obvious that each of them favors a different explanation in regard to functional income distribution. In some respect, the division among them is profound, as is the case with the concept of wages. For example, while the neoclassical emphasizes the supply side rather than the demand side of the economy, and in which the role of wages is limited to being part of the cost without taking into account its impact on the demand side, the post-Keynesian view claims that wages have a dual role affecting both costs and demand.

This division is necessary to understand economic growth according to the post-Keynesian view. According to this view, the redistribution of income towards wages will, on one hand, increase the marginal propensity to consume out of wages, thus there will be an increase in demand. On the other hand, when wage share increases that will be at the expense of profits because it leads to an increase in labor costs, which will adversely affect competitiveness and discourage entrepreneurs from investing. In this sense, they argue that the overall effect of the decline in the share of wages on aggregate demand depends on the relative size of changes in consumption and investment (in an open economy additional effects will operate through net exports) due to changes in income distribution. Thus, when the negative effects on investment, resulting from the redistribution of income out of wages, are lower than those provided by the increase in consumption, then the demand can be said to be wage-led, otherwise, demand is profit-led. This is exactly what the neo-Kaleckian models seek to explore and analyze the conditions for growth, which can be either wage-led or profit-led. Here comes the contribution of Kaleckian models that indicate the possibility of achieving economic growth with more equitable income distribution that would favour the workers. 


\section{ECONOMIC GROWTH AND INCOME \\ DISTRIBUTION IN KALECKIAN FRAMEWORK}

\section{The evolution stages}

The Kaleckian models laid the foundations for many important contributions that tackles topics related to functional income distribution, aggregate demand, capacity utilization, capital accumulation, and growth. The main argument put forward by these models is that the redistribution of income towards wages will lead to an increase in aggregate demand, realized profit rate and capital stock growth rate. This argument was entirely excluded in classical-Marxian or neo-Keynesian models.

Here it is worth noting the difference between the Kaleckian approach and the Kaldorian approach, given that they both considered to be fundamental lines of thought in the theory of income distribution. For instance, unlike the Kaldor-Robinson model, Kaleckian models assume that some sort of monopolistic or oligopolistic competition dominates the markets in which price responds inflexibly to the change in demand and supply. Another difference is related to the rate of capacity utilization. In the Kaleckian models, the rate of capacity utilization is not considered to be exogenously fixed at some normal rate, in this sense, it becomes endogenous in the Kaleckian approach (Hein, 2014).

The main premise of Kaleckian models, which is wage-led growth, was interpreted by the basic model of Kalecki-Steindl under strong assumptions including: no saving out of wages, no foreign trade and strong accelerator effect in the investment function. They claimed that growth can be wage-led due to a combination of two effects, the increase in the aggregate demand resulting from the increase in workers' consumption due to the impact of higher real wages, on one hand, and a strong accelerator effect of the resulting rise in capacity utilization, which enhances realized investment, on the other hand. That is increasing the profit rate, despite the decrease in the profits share (Blecker and Setterfield, 2019).

Later, Kaleckian models became subject to a number of modifications, the most important of which were presented by Rowthorn (1981) and Dutt (1984, 1987), who formed the so-called neo-Kaleckian, or the second generation of Kalecikan model. They independently developed models that treat the capacity utilization and growth rate as an endogenous variable. In these models they consider the investment to be an increasing function of both the profit rate and capacity utilization, unlike the Kaldor-Robinson model wherein only the rate of profit determines the rate of investment growth (Araujo and Teixeira, 2016). Thus, in this sense, while the neo-Kaleckian models assumes that the capacity utilization is endogenous and the profit share is exogenous, the growth effects of aggregate-demand work via capacity utilization. In contrast, the models in the Cambridge growth theory are based on opposite assumptions where the profit share is endogenous and capacity utilization is exogenous, making these models work via the profit share (Palley, 2017).

One of the most important finding of neo-Kaleckian models relates to the possibility of a stagnationist regime, in which the increase in the profit share necessar- 
ily implies a reduction in capacity utilization and economic growth. This finding, as Palley (2014) pointed out, is clearly demonstrated in the model developed by Dutt (1984) where he indicates that if the Keynesian expenditure multiplier stability condition holds, the economy can only be wage-led or conflictive.

However, this result has been challenged by Amit Bhaduri and Steven Marglin in the early 1990s, after making adjustments to the neo-Kaleckian models. They concluded that the stagnation is no longer one of its necessary outcomes. Furthermore, they also identified a completely opposite situation in which the demand for investment responds positively to the increase in the profits share and called this case "exhilarationism". They also argue that the "exhilarationism" case can be seen in the context of international price competition. The increase in external competitiveness resulting from the redistribution of income towards profits, and consequently the decrease in domestic expenditures, may have a significant positive impact on the trade balance in a manner that may lead to increased aggregate demand and economic growth (Blecker, 2002).

The classical neo-Kaleckian model for a closed economy indicates that the demand is wage-led, which is an increase in the wage share will always lead to an increase on capacity utilization and consequently boost the demand. Nevertheless, this fundamental result does not remain the same when some assumptions from the original model are relaxed. For example, the use of an alternative investment function makes the emergence of regimes of profit-led type possible and makes the results of neo-Kaleckian models no longer limited to wage-led regimes. This was the case when the investment function was modified through the models developed by Bhaduri and Marglin (1990) and Kurz (1990), who later became known as post-Kaleckian models. In a similar vein, Blacker (1989) reached similar conclusions by analyzing neo-Kaleckian models in an economy that are open to international trade. These models have shown that the demand can be either wage or profit-led (Hein and Prante, 2018).

Making room for the possibility of a profit-led economy came through Bhaduri and Marglin's development of a model in which they relied on the profit share rather than the profit rate. In their paper, "Unemployment and the real wage: the economic basis for contesting political ideologies", Bhaduri and Marglin (1990) distinguish among three regimes: wage-led, profit-led, and conflictive growth regimes. Through these different regimes, they clarified the impact of an exogenous change in the profit share. In the case of the wage-led regime, the increase in profit share will reduce capacity utilization and negatively affect economic growth, otherwise, the regime is profit-led when a higher profit share raises capacity utilization and growth. On the other hand, if a higher profit share lowers capacity utilization but increases growth, then the case represents the conflictive regime (Palley, 2017). Thus, the question of whether or not a change in the functional distribution of income is in favor of the factor labor promotes economic growth and employment becomes an empirical one. 


\section{Is Aggregate Demand Wage-led or Profit-led?}

The contributions of Bhaduri and Marglin (1990) have greatly influenced post-Keynesian thinking. Their work on demand regimes has been the driving force of many experimental studies that have sought to determine the type of demand regime that characterizes an economy or another in a given period. These empirical studies contributed, in one way or another, to forming general impression that the economies of the countries are either profit-led or wage-led. This generality has been referred to by Hein and Tarassow (2010: 750) who stated that "the mediumto long-run demand regime in large and medium-sized open economies, as in Germany, France, the UK and the USA, tends to be wage-led, whereas for small open economies, as in the Netherlands and Austria, some studies have obtained profit-led results".

However, despite the significant amount of empirical studies devoted to investigating whether aggregate demand is wage-led or profit-led in a variety of countries, the evidence delivered by these studies was inconclusive. Most likely, this opinion was formed in light of the results obtained from successive empirical studies on a particular economy, some of which were inconsistent or even contradictory with the other.

These conflicting results can be seen in the case of the United States. Hein and Vogel (2008), for example, analyzed the relationship between functional income distribution and economic growth in the USA, as well as a number of European countries, from 1960 until 2005. Their analysis, based on a demand-driven distribution and growth model for an open economy inspired by Bhaduri and Marglin, concluded that the demand is wage-led in the United State. Onaran et al. (2011) also reported the same results. In contrast, Naastepad and Storm (2006) documented in their analysis of the US economy, along with other seven member countries of the OECD, that the USA economy is profit-led, likewise Japan, while they considered the demand regimes in the rest of the countries under study are wage-led.

Blecker (2016) noted that the inconsistency in the results is not accidental and can be explained by taking into account the time dimension of various distributional effects on aggregate demand. According to him, several factors and circumstances are driving the same economies to move between profit-led and wage-led demand regime. For instance, he argued that in the short-term, demand is more likely to be profit-led due to the positive effects of lower labor costs on investment and net exports. Whereas, the positive effects of a higher share of wages on consumption are likely to be stronger in the long run, making demand more likely to be driven by wages in the long-term. Stockhammer (2017) adopts a similar line of argument demonstrating the studies that used reduced-form demand equations, as in the case of neo-Goodwin approach, which often concludes that the economy under study is profit-led since this approach focuses on short-run cyclical effects. On the other hand, those who tend to estimate behavioural equations often yield results indicating demand regimes of a wage-led type. In related context, Jump and 
Mendieta-Muñoz (2017) provided evidence in support of the previous argument by examining the case of the United Kingdom over the period 1971-2007 through the estimation of four VARs models. The estimation results show that positive shocks to real earnings increase both GDP and the labour share, and, therefore, they concluded that aggregate demand in the UK is wage-led.

The contribution made by Blecker (2016) in clarifying the importance of taking into account the time dimension in the framework of economic analysis has important implications at the policy level and helps develop a more complex understanding of the dynamic linkages between income distribution and economic performance. There is no doubt that profits drive more investment and thus lead to more growth, but that is true within the framework of a typical business cycle. However, in the long term, growth is not expected to be achieved through policies that focus on a continuous increase in the share of profits of income, because the adoption of such policy is offset by a decrease in the share of wages, which reduces the utilization and consequently impedes the increase in growth. Nikiforos (2016) mentioned that if the argument stipulating that an increase in the share of profits or wages is continuing then this would lead to a continuous increase in the growth rate. However, this would indicate that the maximum growth rate will be achieved when the wage or profit share is zero, which cannot be the case.

Palley (2014) developed this argument further by asking whether the economy could actually be classified as wage-led or profit-led. He believes that the economy cannot be subject to such a classification because the nature and determinants of economics are closely related to the policy and changes with its change, which makes it useless to focus on whether a particular economy is wage or profit-led in isolation of the broader context. The focus of many studies on the type of the demand regime must be accompanied by its policy implications, otherwise, they will appear as they assume, implicitly, that the nature of the economy is "exogenously determined by deep primitive parameters". Palley (2014) emphasize that such assumption is incomplete since it does not take into account the fact that the nature of the economy is also determined by endogenous factors subject to policy influence.

In related context, Lavoie and Stockhammer (2013) emphasized the importance of distinguishing between two concepts: first one relates to the distribution policies that governments choose to follow, and which are either pro-labour or pro-capital policies. The second concept relates to the country's structural macroeconomic features that are either wage-led and profit-led. He adds that the existence of an interaction between the two concepts should not lead to confusion among them, as the distributional policies which are the determinants of the income distribution, while the economic regime represents the effects of changes in the distribution of income on the economy. 


\section{The shift between wage-led and profit-led growth}

According to Nikiforos (2016), since the income distribution behavior is fundamentally unstable, the shift between wage-led and profit-led growth (and vice versa) seems possible. He focused on his study on analyzing these two phases in the long run, and suggested that an endogenous mechanism causes the economy to fluctuate between wage and profit-led periods. Therefore, Nikiforos (2016: 400) concluded that "wage-ledness and profit-ledness are not global properties of an economy in time: there are periods during which an economy is wage-led and there are periods during which it is profit-led". He also agrees with the argument made by Palley (2014), which was mentioned previously, about the importance of identifying the 'distribution-ledness' of an economy, as well as the analysis of its direction, at a certain period of time.

Theoretically, the shift between wage-led and profit-led seem likely to happen because what determines the form of the economic regimes depends on the slope of the investment-saving curve. Palley (2014) shows how different systems can be distinguished by referring to the slope of the IS condition in $[\mathrm{u}, \sigma]$ space, which is given by: $d \sigma /\left.d \mathrm{u}\right|_{\mathrm{IS}}=\left[\mathrm{S}_{\mathrm{u}}-I_{\mathrm{u}}\right] /\left[I_{\sigma}-\mathrm{S}_{\sigma}\right]$. Since the model assuming the holding of the Keynesian expenditure multiplier condition, the numerator in the previous equation will be positive. Thus, the slope signal depends on the sign of the denominator, which represents the relative sensitivity of the investment and savings rates to changes in the profit share.

In this sense, if $\left(I_{\sigma}-S_{\sigma}>0\right)$, that is, when the increase in investment exceeds the increase in savings, then IS will be positive. This case means that the economy is profit-led because the increase in the share of profits leads to increased capacity utilization. On the other hand, the reverse situation, when the economy is wage-led, indicates that the increase in the profit share did not cause an increase in the capacity utilization, which made the increase in investment less than saving $\left(\mathrm{I}_{\sigma}-S_{\sigma}<0\right)$, the IS slope will be negative. Meanwhile, a subset of wage-led economies, so-called conflictive economies may emerge. In such case, the IS schedule is also sloped negatively, but the decrease in capacity utilization is associated with an increase in the rate of accumulation and growth. This is because the investment, in this case, is very sensitive to the share of profits.

\section{Modification and innovations into a Kaleckian growth framework}

Since early 2000, Neo-Kaleckian models have become widely present in the areas of economic analysis and regarded as the backbone of the post-Keynesian macroeconomic theory. These models have inspired a flourishing literature of empirical research. Moreover, research in the Kaleckian tradition has recently produced a number of modifications. For example, Palley (2015) explore economic inequality by modifying Bhaduri and Marglin model to include a three-class model with capitalists, managers, and workers (Hein, 2018). Moreover, in light of financial 
globalization and the increase in lending, Kapeller and Schütz (2015) explores the implications of financial globalization and the increase in lending on the relationship between distribution and growth. They suggested that such effect contributed to transforming the relationship between distribution and growth in a way that allowed the possibility of a "consumption-driven, profit-led" growth regime. In related context, and based on Kaleckian-Steindlian approach, the aspect concerns the "wealth effect" on consumption is noted by Onaran et al. (2011), since financialization has opened up the possibilities for consumption that financed by debt. This is what they show in the case with the US economy, which witnessed, during the periods of a declining wage share an increase in consumption.

Furthermore, Oreiro and Araujo (2013) pointed to one aspect that has long been neglected in post-Keynesian literature, which is the importance of the relationship between the level of the real exchange rate and growth. They argued that the accumulation rate depends not only on the rate of capacity utilization and the share of profits, but also on the exchange rate. Therefore, through the construction of a nonlinear macrodynamic model for an open economy, they analyse the relationship among economic growth, income distribution and real exchange rate, and they concluded that during periods of exchange rate overvaluation, the accumulation regime was profit-led while the period of exchange rate undervaluation indicates that the accumulation regime was wage-led. Based on their neo-Kaleckian model of growth and income distribution for an open economy, they estimated that the accumulation system in Brazil after the last quarter of 2005 is profit-led.

\section{CONCLUSION}

For decades, the ideas promoted by mainstream economists were considered to be taken seriously and beyond doubt. This line of economic thoughts promoted the logic of "trickle-down economics". In such notion, policies that increase unit profits at the expense of unit wages have positive effects for the economy as a whole because they encourage investments and entrepreneurship, stimulating demand for products and for labor, and ultimately increasing the size of the pie to the benefit of everyone.

However, the last crisis and the current stagnation raised doubts on such ideas that were unanimous by many economists and open the door for the possibility for another possible growth strategies. Here the return to the Kaleckian literature provides us with a better understanding of issues of economic growth and income distributions. For this purpose, this paper presents the aspects of the evolution of economic growth theory, in a manner that serves the recent debate on wage-led and profit-led regimes. 


\section{REFERENCES}

Araujo, R.A. and Teixeira, J., (2016). "Growth Regimes in a Structural Economic Dynamic Approach to the Neo-Kaleckian Model". Brazilian Keynesian Review, 2(1), pp. 26-39.

Arestis, P. , Sobreira, R. and Oreiro, J.L. eds., (2010). An assessment of the global impact of the financial crisis. Springer.

Baccaro, L. and Pontusson, J., (2016). "Rethinking comparative political economy: the growth model perspective”. Politics \& Society, 44(2), pp. 175-207.

Bhaduri, Amit; Stephen Marglin (1990) "Unemployment and the real wages: the economic basis for contesting political ideologies", Cambridge Journal of Economics, 14 (4) December: 375-393.

Blecker, R.A., (2002). Distribution, demand and growth in neo-Kaleckian macro-models. The Economics of Demand-led Growth, Cheltenham: Edward Elgar, pp. 129-152.

Blecker, R.A., (2016). "Wage-led versus profit-led demand regimes: the long and the short of it". Review of Keynesian Economics, 4(4), pp. 373-390.

Blecker, R.A. and Setterfield, M., (2019). Heterodox Macroeconomics: Models of Demand, Distribution and Growth. Edward Elgar Publishing.

Hein, E., (2014). Distribution and growth after Keynes: A Post-Keynesian guide. Edward Elgar Publishing.

Hein, E., (2015). "Finance-dominated capitalism and re-distribution of income: a Kaleckian perspective." Cambridge Journal of Economics, 39(3), pp. 907-934.

Hein, E. and Prante, F., (2018). "Functional distribution and wage inequality in recent Kaleckian growth models” (No. 110/2018). Working Paper, Institute for International Political Economy Berlin.

Hein, E. and Tarassow, A., (2010). "Distribution, aggregate demand and productivity growth: theory and empirical results for six OECD countries based on a post-Kaleckian model". Cambridge Journal of Economics, 34(4), pp. 727-754.

Hein, E. and Vogel, L., (2008). "Distribution and growth reconsidered: empirical results for six OECD countries”. Cambridge Journal of Economics, 32(3), pp. 479-511.

ILO. (2013). Global Wage Report 2012/2013: Wages and equitable growth, Technical Report, Geneva, International Labor Organization.

Jump, R. and Mendieta-Muñoz, I., (2017). "Wage led aggregate demand in the United Kingdom”. International Review of Applied Economics, 31(5), pp. 565-584.

Kapeller, J. and Schütz, B., (2015). "Conspicuous consumption, inequality and debt: the nature of consumption driven profit led regimes". Metroeconomica, 66(1), pp. 51-70.

Kohler, K., Guschanski, A. and Stockhammer, E., (2019). "The impact of financialisation on the wage share: a theoretical clarification and empirical test". Cambridge Journal of Economics, 43(4), pp. 937-974.

Lavoie, M., (2017). "The origins and evolution of the debate on wage-led and profit-led regimes". European Journal of Economics and Economic Policies: Intervention, 14(2), pp. 200-221.

Lavoie, M. and Stockhammer, E., (2013). "Wage-led growth: Concept, theories and policies”. In Wage-led growth (pp. 13-39). Palgrave Macmillan, London.

Naastepad, C.W.M. and Storm, S., (2006). “OECD demand regimes (1960-2000).” Journal of Post-Keynesian Economics, 29(2), pp. 211-246.

Nikiforos, M., (2016). "Distribution-led growth in the long run". Review of Keynesian Economics, 4(4), 391-408.

Onaran, Ö., Stockhammer, E. and Grafl, L., (2011). "Financialisation, income distribution and aggregate demand in the USA". Cambridge Journal of Economics, 35(4), pp. 637-661.

Oreiro, J. L. (2018). Macrodinâmica pós-keynesiana: crescimento e distribuição de renda. Alta Books.

Oreiro, L.J. and Araujo, E., (2013). "Exchange rate misalignment, capital accumulation and income distribution: theory and evidence from the case of Brazil”. Panoeconomicus, 60(3), pp. 381-396. 
Oreiro, J.L., Nakabashi, L., Costa da Silva, G.J. and Guimarães e Souza, G.J., (2012). “The Economics of Demand Led-Growth Theory and Evidence for Brazil”. Cepal Review, 106, pp. 151-168.

Palley, T.I., (2014). "Rethinking wage vs. profit-led growth theory with implications for policy analysis" (No. 141). IMK working paper.

Palley, T.I., (2017). "Inequality and growth in neo-Kaleckian and Cambridge growth theory". Review of Keynesian Economics, 5(2), pp. 146-169.

Ricardo, D., 1891. Principles of political economy and taxation. Batoche Books Kitchener.

Setterfield, M., (2002). The economics of demand-led growth. Edward Elgar Publishing.

Stockhammer, E., (2015). "Rising inequality as a cause of the present crisis". Cambridge Journal of Economics, 39(3), pp. 935-958.

Stockhammer, E., (2017). "Wage-led versus profit-led demand: what have we learned? A KaleckianMinskyan view". Review of Keynesian Economics, 5(1), pp. 25-42.

Stiglitz, J.E., (2016). “Inequality and economic growth”. In Rethinking Capitalism (pp. 134-155). 